\title{
Green Manufacturing: A New Path toward Sustainable Industrialization in China
}

\author{
Yan Yang ${ }^{1,2}$, Limao Wang ${ }^{3 *}$, shuzhong $\mathrm{Gu}^{4}$ and Jianlin Yan ${ }^{1}$ \\ ${ }^{1}$ Chinese Academy of Engineering, Beijing 100088, China \\ ${ }^{2}$ Department of Chemical Engineering, Tsinghua University, Beijing 100084, China \\ ${ }^{3}$ Institute of Geographic Sciences and Natural Resources Research, Chinese Academy of Sciences, China \\ ${ }^{4}$ Institute of Resources and Environmental Policy, Development Research Center of the State Council, China
}

Submission: December 13, 2017; Published: December 21, 2017

*Corresponding author: Limao Wang, Institute of Geographic Sciences and Nature Resources Research, Chinese Academy of Sciences, 11A Datun Road, Chaoyang District, Beijing 100101, China, Tel: +86 10 59300247; Fax: +86 10 59300246; Email: Imwang2016@163.com

\section{Introduction}

No one can deny that in recent years the need to "save the planet" from global environmental deterioration has become one of the most pervasive issues of our time [1-4]. China, the second largest economy in the world, has an inescapable responsibility to protect the ecological environment of human beings [1]. China's industrial economy with high growth has made remarkable achievements since the Policy of Reform and Opening up in 1978. But at the same time, the extensive growth mode of high consumption, high emission and low efficiency has brought a series of serious problems regarding resources, environment, ecology and social livelihood [2]. How to tackle the contradiction between economic growth and eco-environmental protection becomes a tough problem for China. That is to say, China is in desperate need for reducing emissions of greenhouse gases and pollutants in industrial areas, achieving efficient, clean, lowcarbon, recycling and sustainable development.

In order to solve the development problems and construct a beautiful country, the $18^{\text {th }}$ National Congress of the Communist Party of China (CPC) put forward "vigorously promote the construction of ecological civilization", and put it into the overall layout of the cause on socialism with Chinese characteristics; afterwards, the Fifth Plenary Session of the $18^{\text {th }}$ Central Committee of the CPC further proposed the five development concept of "innovation, harmony, green, open, sharing"; lately, the $19^{\text {th }}$ National Congress of the CPC pushed the concept of ecological civilization and green development to an unprecedented height. These significant decisions have pointed out the direction and road for solving the above problems of unsustainable development [5]. In other words, China's industrialization has entered a new stage from rapid growth to the development of high quality. China needs to accelerate the transformation of development mode of the economy which takes manufacturing as the main body and improve the quality and efficiency of development, to achieve a green and sustainable industrialization which characterized by low resources consumption, little environmental pollution and progressive ecological civilization.

Green Manufacturing: the harmonization between manufacturing industry and ecological environment

Manufacturing is the main body of a country's competitiveness. The realization of China's grand development goal depends on the construction of a powerful manufacturing country. The relation between manufacturing industry and ecological environment presents mutual influence and restriction. Green manufacturing is a critical focus in the construction of manufacturing power and in the transformation of production modes. Moreover, green manufacturing is an important part of green development. The so-called green manufacturing, which has the essence to promote the harmonious coexistence between manufacturing industry and ecological environment, is a modern manufacturing mode with the comprehensive consideration of the needs of people, environmental impact and resource efficiency and enterprise efficiency [5]. Thus, the goal of green manufacturing is to minimize the environmental impact in the whole product-life cycle from design, manufacture, and use to scrapping, as well as to minimize resource utilization and energy consumption.

\section{Use green manufacturing as the guide to promote China's sustainable industrialization}

Green manufacturing is a new way to solve the contradiction between economic growth and environmental protection, to promote the harmonious symbiosis between human society and nature and achieve a green and sustainable industrialization. China's road of new industrialization makes it necessary to accelerate the harmonization between manufacturing industry and ecological environment using green manufacturing as the guide [5]. On the one hand, China should completely abandon the 
traditional industrialization mode of high input, high consumption, high pollution and low level of quantity expansion. The goal of resource utilization efficiency improvement and carbon/ pollutant emission reduction could be realized through the structural adjustment of manufacturing industry, technological innovation driving, and policies \& regulations security measures. On the other, China should put the concept of green development into various aspects and the whole process of industrialization development, and build a modern green manufacturing system to promote the formation of new manufacturing mode of green, lowcarbon, recycling development.

\section{References}

1. Yang Y, Wang L M, Fang Y B (2017) Integrated value of shale gas development: A comparative analysis in the United States and China. Renewable and Sustainable Energy Reviews 76: 1465-1478.
2. Jin Y, Arons J (2009) Resource. Energy. Environment. Society-Scientific and Engineering Principles for Circular. Economy [M]. Beijing: Chemical Industry Press, China.

3. Du X W, Wen Z G, Wang N (2015) The backdrop and significance of ecological civilization construction. Strategic Study of CAE 17(8) 8-15.

4. Xu D L, Cui Y S, Li H (2015) On the future of Chinese cement industry Cement and Concrete Research 78: 2-13.

5. Chinese Academy of Engineering (2016) Research on manufacturing power strategy_green manufacturing thematic volume [M]. Beijing: Publishing House of Electronics Industry, China.
This work is licensed under Creative Commons Attribution 4.0 Licens DOI: $10.19080 / I J E S N R .2017 .07 .555722$ 